\title{
FROM WORKER TO BUSINESS OWNER: UNDERSTANDING CHALLENGES FACING SMALL BUSINESS AMIDST COVID-19 OUTBREAKS
}

\author{
Nana Trianasari \\ Master of Management Program, Universitas Pendidikan Ganesha, Indonesia. \\ E-mail: nanatrianasari01@gmail.com
}

\begin{tabular}{|c|c|}
\hline ARTICLE INFO & ABSTRACT \\
\hline 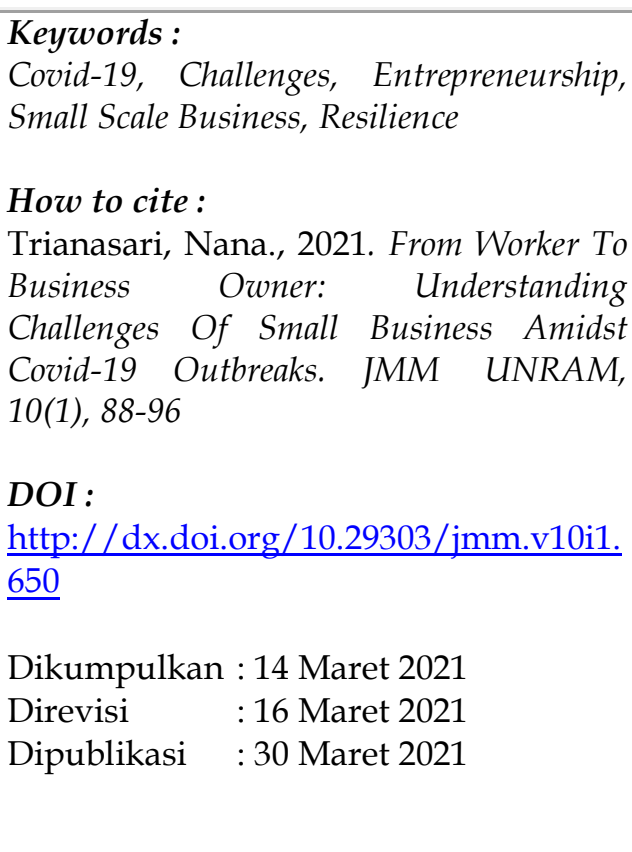 & $\begin{array}{l}\text { The Covid-19 pandemic has caused the unprecedented } \\
\text { impacts to almost all aspects of human live globally. } \\
\text { Travelling and tourism activities are among the most } \\
\text { devastating sectors. Being one of the worldly known } \\
\text { tourist destinations where over } 80 \% \text { of the local people } \\
\text { rely on the tourism sector, Bali is particular case during } \\
\text { this Covid-1 outbreak. People who work in the tourism } \\
\text { field has been pushed to transform their job in order to } \\
\text { survive. Addressing the research gaps, this paper reports } \\
\text { the findings of a study that aimed to explore the } \\
\text { challenges among hotel/tourism workers in Bali in } \\
\text { running small business amidst Covid-19 pandemic. Data } \\
\text { were collected from } 16 \text { participants using semi structure } \\
\text { interview and were analyzed using a qualitative } \\
\text { approach. The study revealed four categories representing } \\
\text { the challenges of business owner which are lack of } \\
\text { management skills, insufficient funding and facilities; } \\
\text { lack of creativity and innovation; and lack of experiences. } \\
\text { Further discussion, implication, limitation and future } \\
\text { research direction are presented. }\end{array}$ \\
\hline & $\begin{array}{l}\text { Copyright (c) 2021. Nana Trianasari. All rights } \\
\text { reserved. }\end{array}$ \\
\hline
\end{tabular}

\section{INTRODUCTION}

Among other disastrous events during the past decade, Covid-19 pandemic is the most significant (Zenker \& Kock, 2020) for almost all countries across the globe. This virus is said to be highly infectious and contagious (Chang et al., 2020), quickly mutates (Uğur \& Akbiyık, 2020), and have more negative and long lasting impacts (Prayag, 2020) including global economic, political, psychological, as well as socio-cultural system(Sigala, 2020a). First found in Wuhan, China in the late 2019, this virus has spread out to almost all parts of the world in less than one semester and has killed millions of people. Accordingly, WHO has announced that Corona Virus is a pandemic in March, 2020.

One of the most impacted sectors of Covid-19 pandemic is tourism. This is particularly true as tourism is somewhat fragile. It is easily distressed by global crisis (Ugur 
\& Akbiyık, 2020). Thus, it is not surprising that as the cases of Covid-19 grow, the tourism sector deteriorates. It is largely because this sector relies on the travelling activities of people whether individually or in group. Many countries or regions are forced by this pandemic situation to decide and implement the lockdown policy where there are limitation and restriction for people to travel in or out a country or region. This phenomenon leads to an unavoidable economic downturn, particularly in a destination like Bali where more than $80 \%$ people rely on the tourism sector (Trianasari \& Dharma, 2020).

The sudden changes of situations in terms of the number of visitor and business activities in the tourist objects and destinations have been dramatically devastating. The tourist sites including facilities such as hotels, restaurants, transportation, and the kinds have inevitably closed down. Thus, the tourist villages or destinations become empty and quiet. From this phenomenon, several questions emerged. While tourists returned to their origin countries or regions, where are the hotel or tourism workers? What do they do to provide for their family? How do they cope with this situation?

A recent research on resilience and adaptive behaviour of local hotel or tourism workers has found that many hotel/tourism workers sell products (Trianasari \& Dharma, 2020). Previous research has also shown that when confronting crises, people's sense of entrepreneurship arose (Deborah et al., 2015). However, it may not immediately results in a success story, because mostly they may not be prepared to run a business however small. Thereby, the question of what are the challenges when transforming the way to earn money facing hotel/tourism workers requires investigations.

While a number of works have been dedicated to investigate entrepreneurial context during Covid-19 pandemic (see Deborah, Wilhelmina, Oyelana, \& Ibrahim, 2021; Maritz, Perenyi, de Wall, 2020; Ratten, 2020), little has focused on small scale business and how workers transform their source of income (among a few, see for example the work of Lucky \& Rosmadi, 2021; Salman, 2021; Trianasari \& Dharma, 2020). In fact, this area of focus is arguably essential due to during Covid-19 condition, becoming entrepreneur or business owner is one of the key ways to survive (Adisa et al., 2014). However, challenges and obstacles in operating such business have not been resolved (Deborah et al., 2021). Moreover, previous research has also alarmed the importance of academia to help the performance of small businesses especially in developing countries (Deborah et al., 2021). In other words, there have been calls for further investigation within the entrepreneurial or small business areas particularly during Covid-19. Thus, to address these gaps, this study aims to explore what challenges facing ex-hotel/tourism workers in running their own business. Furthermore, to achieve these purposes, first, this paper review relevant literature which are the impacts of Covid-19, entrepreneurial skills, and resilience. By doing so, the paper identifies key issues within the literature that related to the topic under study. The paper continues by presenting the research method of this study. Next, responding to the call to address the research gaps, the findings are discussed based on reconfirming and adding to the current literature. Finally, the limitation and future research directions are presented in the conclusion section. All in all, this research provides an empirical evidence of what challenges facing ex-tourism/hotel workers in Bali when transforming themselves from worker to become a business owner amidst Covid-19 pandemic condition.

\section{LITERATURE REVIEW}

\subsection{The impacts of Covid-19}

Covid-19 pandemic has impacted almost the whole globe. In Indonesia the virus was first identified in March 2020. The case grew rapidly within the same month. As in 
other countries, Indonesian people have been suffering from this pandemic outbreak. When it comes to the impact of Covid-19 pandemic, Bali is a particular case, because the island depends highly on tourism. That is, more than $80 \%$ of the local people in Bali rely on the tourism sector (Trianasari \& Dharma, 2020). With the regulation of the government of Bali and Indonesia to limit the social activities and some areas were locked down, the international and domestic arrivals have declined dramatically. Thus, the tourism sector sharply fell to the lowest level. For almost all of tourism firms, it has led to business closure. In fact, there have been more and more hotels being sold, including the four to five star and international chained hotels. Restaurants, souvenirs shops, and other tourism related firms experienced the same situation. The worst case scenario that may be unavoidable is bankruptcy.

Previous research has discussed the significant impacts of Covid-19 (Prayag, 2020) such as on the global economic, political, psychological, as well as socio-cultural systems (Sigala, 2020b). It was also highlighted that this pandemic is different from any previous crises and outbreaks. Moreover, this virus has signaled its long term impacts. As such, being a fragile and sensitive industry, the tourism has to demonstrate extra resilience efforts.

With the significant and long term impacts of Covid-19 pandemic, the previous ways of living life are unlikely to retrieve. The so called "new normal" that represents health protocols has been implemented in almost all aspects of life. Such protocols include wearing mask, washing hands, and maintaining distance. Within the travel and tourism industry, the implementation of the health protocols involves technology as to adopt the touch-less concept (Sigala, 2020b).

\subsection{Small Scale Business and Entrepreneurial skills}

The majority of businesses have dramatically slowed down due to Covid-19 pandemic. The tourism industry is a particular case due to its heavy reliance on the people who travel. This pandemic condition has stopped the tourism activities for an uncertain period.

While hotels are empty which resulted in leaning and laying over decisions, the employees are forced to do something else to survive. A recent research conducted by Trianasari and Dharma (2020) showed the resilience and how ex-tourism workers continued to provide for their family. Her study revealed four categories of survival efforts which are back to basic, back to nature and home, back to selling, and back to oneself."Back to basic" refers to the focus of primary needs and less consumption. The theme "back to nature and home" represents the decision of research participants to go home to their village. This reflects that the respondents were no longer able to afford the cost of live in the city. The theme "back to oneself" represents the willingness of participants to work on self development program which is mostly conducted online. The theme "back to selling product" refers to creating small business.

Other research has reported that efforts and steps taken by micro, small, and medium enterprises (MSMs) in Indonesia during the Covid-19 pandemic are highly dependent on the human resources creativities and innovations (Lucky \& Rosmadi, 2021). This study also emphasized that the lack of support from the government and banks has been a primary obstacle. In other words, the role of government and banking sectors are important.

Studies on the human resources in MSMs within the Indonesian context have revealed that the quality of the human aspects are likely to bring the business to success in the globalized environment (Faizal et al., 2018), Kalil \& Aenurohman, 2020). One of the 
triggers of entrepreneurial skills is resilience (Portuguez Castro \& Gómez Zermeño, 2020). In order to survive, the human resources aspects need to be used to an optimal level (Lucky and Rosmadi, 2021). Thereby, during the pandemic situation, creativity and innovation have been a great challenge.

During this pandemic condition, the majority of people in Bali have been trying to operate their own business. However, it may not be easy and smooth, due to the high competition. Thus, business and entrepreneurial skills have growingly become a necessity. Although the literature has emphasized the difference between small business owner and entrepreneur, such skill is characterized by the ability to develop new ideas that provide value for customers (Fisher et al., 2020) and to create new products and process, or improve the existing ones (Martens et al., 2018). Being innovative (Portuguez Castro \& Gómez Zermeño, 2020) in generating ideas and products or services is seemingly more crucial in this pandemic situation.

\subsection{Resilience}

Resilience represents the individual's capacity to endure, develop, and recover from adverse conditions (McCubbin, 2001). In practical, such capacity is important not only for individuals but also for organization and society (Liu et al., 2020). Within the context of entrepreneurship, resilience refers to the adaptability of an entrepreneur toward changes (Salisu et al., 2020). In this pandemic situation, resilience is one of the most frequent research topics, especially to address the impacts of the global pandemic (Sawalha, 2020). Nevertheless, there are still calls for further investigation on the resilience in individual level (Trianasari \& Dharma, 2020). Indeed, it is still unclear how individuals who operate their small to medium scale of business.

In research, there are several possible ways to conceptualize resilience. Among others, it can be seen from two perspectives which are outcome and process (McCubbin, 2001). As an outcome, resilience is often viewed as dichotomies of poor and positive. That is, individuals or organizations can become worse (vulnerable) or better (invulnerable). As a process, resilience moderates the outcome. In other words, it can cause a positive or negative outcome. However, this categorization has led to confusion of whether it is an outcome or a process.

While there has been numerous research on resilience, the focus was mainly on company or organization (Prayag, 2020). Little work has been dedicated within the context of ex-tourism/hotel workers (Trianasari \& Dharma, 2020). As such, there is still a call for further research within the impact of Covid-19 pandemic from this perspective.

\section{RESEARCH METHOD}

To achieve the established research purposes, this research employed a qualitative approach which allows identifying and extracting relevant information on subjects of interest from the existing literature (Kitchenham and Charters, 2007). Data were gathered using semi structure interview. Self-developed questions related to research questions were developed to guide during the interview process (Puhakka, R., Cottrell, S. P., \& Siikamäki, 2013). The interview guide includes general questions and main questions. The general questions served as introduction that consist of questions related to the participant's feeling and general situations before and during the outbreaks. The main questions consisted of more detailed entrepreneurial or business experiences such as "How did you decide your business?";What did you experience when starting to run your own business?"; "How did you feel about your business?"; "Do you like it?";"Was it easy or not?"; “Did you find any

jmm.unram.ac.id 
difficulties or obstacles?. That is about constraints or difficulties and dis/satisfactory feelings. Then, data were analysed using coding and constant comparative method (Milles \& Huberman, 1994) which has been largely employed in qualitative data analysis (Leech, N. L., \& Onwuegbuzie, 2007). The raw data were first transcribed. The data analysis involved three coding steps which were open coding, axial coding, and reflexive coding. During the open coding, similar terms were grouped and labelled. Next, the axial coding involved observation of data pattern. The final stage was identification of theme.

\section{FINDINGS AND DISCUSSION}

Data were gathered from 16 ex-hotel/tourism workers in Bali consisting of $70 \%$ males and 30\% female, aging from 24 to 51 years. Almost all of participants lived in the Southern part of Bali, where the tourism activities mostly existed. The interviews were conducted either off line or online; using Indonesian language; recorded and carefully transcribed. The analysis of the data showed four themes that represent challenges facing small business owners to start or operate their own business during Covid-19 pandemic. They are lack of management skills; insufficient funding and facilities; lack of creativity and innovation; and, lack of experience. These findings are contrasted to previous research. A more detailed interpretation and discussion is presented below.

\subsection{Lack of management skills}

In line with the work of (Adisa et al., 2014; Rootman Chantal \& Kruger Janine, 2010; Zafar \& Mustafa, 2017), the majority of research participants reported that the most challenging factor in operating their own business was lacking of management skills. These skills include marketing and promotion; record keeping, separating business and personal money, managing employee, and generating creativity and innovation aspects. These aspects represent core functions or divisions of management which are marketing, financial, human resources, and operations.

A few participants explained that they had obstacles in promotion, marketing, and sales. On the other side, many of the participants described that they use social media as the main marketing tool. Managing consistency in promoting their business is another case several participants struggled with.

The next aspect of management is about keeping record of the transactions. One male participant stressed that he had difficulties when it came to book keeping of the transactions. He further reasoned that it needed more time and effort to do it which he failed to do. For some participants, this leads to the inability to separate personal and business money. In other words, many participants reported that they did not have a separate account of business and personal money. This issue was equally stated by male and female participants, including the one who had problem in recording the transactions. Apparently difficulties in being professional in financial management are one of the weakness or challenges for small business owners.

The last element related to business management is with regard to managing human resources. This aspect was discussed by one male participant. She explained that the main challenge was having loyal and motivated employees. The discipline of her employees was somewhat problematic. She further described that she found her employees were lazy despite the economic impact of Covid-19 pandemic. This piece of finding is consistent with the work of (Lucky and Rosmadi, 2021). 


\subsection{Insufficient fund and facilities}

Capital is the second challenging factor facing the small business owners under study. This includes financial and supporting facilities. Previous research has also revealed this aspect. See for example, the work of (Adisa et al., 2014; Rootman Chantal \& Kruger Janine, 2010; Zafar \& Mustafa, 2017). One of the underlined habits of ex-hotel/tourism workers explored in the study was being less attentive toward consistent saving. Thus, in the time of crises, they reported that financial was a big issue. A female respondent said that applying a bank loan was not easy because they already had a current loan.

One of the key factors that lead to the success or failure of small scale business and entrepreneurship is financial management (Rootman Chantal \& Kruger Janine, 2010). It is especially true during the time of challenging economy. Thereby, this aspect is said to need focus and adjustment (Rootman Chantal \& Kruger Janine, 2010).

\subsection{Lack of creativity and innovation}

The challenging aspect in operating small business found in this study is creativity and innovation. This aspect was put forward by both male and female participants. They explained that during the pandemic situation, many people sell similar products. All respondents emphasized that they enter a market with a product that is already in the market. Thus, in order to compete, it is important to have unique, creative, and innovative products. These seem to be difficult to attain. Product diversification is an important strategy.

It is apparent that creativity and innovation cannot be ignored when operating business. In the literature, this aspect is particularly discussed within the realm of entrepreneurship. Although it is used interchangeably with the term small business or selfemployment, entrepreneurship highlights several characteristic such as ambition to grow a business, innovativeness(Henrekson \& Sanandaji, 2014), risk taking, proactiveness, autonomy and competitive aggressiveness(Martens et al., 2018). Furthermore, Kamaluddin (2019) emphasized the importance of product innovation and market orientation for small scale business.

\subsection{Lack of experience}

The next challenging aspect in running small business is related to the lack of experience. This is particularly true due to the participants were hotel workers or tourist guides. That means, their previous work was mostly related to a specific or one unit or department. Whereas, when running their own business, they need to think the whole business aspects and to act from zero. They explained that they were inexperienced in conceptualizing, planning, and executing the business.

One female participant who involved in food business added her explanation, "I intended to do business. But when it comes to deliver the product such us going to the market or shops, I am a kind of resistant. The sound in the back of my head seems like saying that it is not really my job. I am not supposed to do this kind of thing......Well, I realized that I did not have any previous experiences to interact with people in the market or outlets or shops and to deal with such environment." The respondent further stressed that this lack of experience has somewhat discouraged her to fully focus on her business. Perhaps, looking into this aspect from different view, previous experience may not be required for all types of business, although it helps smoothened the business operation. Rather than focusing more on experiences, conceptualizing a business idea may serve as the important foundation, particularly in the beginning. 


\subsection{Theoretical Implications}

The findings in this research are in line with the one found in the work of (McClelland et al., 2005), which however focused on women. Previous research has also highlighted these aspects are one of the challenges for small scale business owners (Rootman Chantal \& Kruger Janine, 2010). In other words, this research has shed lights in terms of identifying the search for potential solutions to address the operational challenges in operating business.

\subsection{Practical Implications}

These findings suggest that there are still challenges in starting and operating small business facing small business owners that need to be addressed. In fact, as largely discussed within the small medium enterprises literature, the small scale of business is said to be the backbone of region or national economy (Adisa et al., 2014).Thereby, it is essential to help such business to grow, develop, and improve its performance. Thus, unless the key findings are addressed properly, the business owners will continue to experience such challenges.

\section{CONCLUSION}

As presented and discussed in the previous section, the analysis provides empirical evidence within the context of small business during Covid-19 pandemic. This study has categorized four themes that represent challenges facing ex-tourism/hotel workers in Bali in running their business amidst Covid-19 pandemic. The themes are lack of management skills; insufficient funding and facilities; lack of creativity and innovation; and, lack of experience. The results of the study imply that it needs involvement of other parties such as government and academia to help people run their business better, for example by providing training, loan or financial aids.

While contributions of the study are reported, its limitations are also acknowledged. It is particularly in terms of the methodology used in this research which is qualitative. Referring to the nature of the qualitative approach, the main disadvantage is that the findings of the study are not immediately available for generalisation to a wider population (Mc_lelland et_ al____2005)as it may be found in a quantitative study in which the results of the study are statistically tested. That being said, the results of this study represent the context under study where participants are from Bali. Culture may be an issue to address. Thus, replication of the study may be conducted in similar context.

Future research may look deeper into (dis)confirming the differences between supervisor or manager and, rank and file employees when facing challenges in changing their work. That is grouping respondents based on the level of employment and comparing differences. It may also be of interest to explore how ex hotel/tourism workers implement their skills at their previous work into the business they run. Furthermore, conducting a longitudinal study to investigate the sustainability of small businesses during Covid-19 should bring insights within the small scale business or entrepreneurial literature.

\section{Acknowledgements}

The authors of this article wish to thank Program Pascasarjana Universitas Pendidikan Ganesha for the supports and facilities provided during the research process. 


\section{REFERENCES}

Adisa, T. A., Abdulraheem, I., \& Mordi, C. (2014). The Characteristics and Challenges of Small Businesses in Africa: An Exploratory Study of Nigerian Small Business Owners. III(LXVI), 14.

Atieno, O. P. (2009). AN ANALYSIS OF THE STRENGTHS AND LIMITATION OF QUALITATIVE AND QUANTITATIVE RESEARCH PARADIGMS. 13, 6.

Chang, C.-L., McAleer, M., \& Ramos, V. (2020). A Charter for Sustainable Tourism after COVID-19. Sustainability, 12(9), 3671. https:// doi.org/10.3390/su12093671

Deborah, A. E., Wilhelmina, S., Oyelana, A. A., \& Ibrahim, S. I. (2015). Challenges Faced by Women Entrepreneurs and Strategies Adopted by Women Entrepreneurs to Ensure Small Business Success in Nkonkobe Municipality, South Africa. Journal of Economics, 6(1), 37-49. https:// doi.org/10.1080/09765239.2015.11885015

Faizal, M., Nara, M. L., \& Nurdiyanto, H. (2018). Barriers and Challenges af Information Technology in Labour Intensive Business Organization. International Journal of Engineering \& Technology, 7(2.5), 104-107.

Fisher, G., Stevenson, R., \& Burnell, D. (2020). Permission to hustle: Igniting entrepreneurship in an organization. Journal of Business Venturing Insights, 14, e00173. https://doi.org/10.1016/j.jbvi.2020.e00173

Henrekson, M., \& Sanandaji, T. (2014). Small business activity does not measure entrepreneurship. Proceedings of the National Academy of Sciences, 111(5), 1760-1765. https://doi.org/10.1073/pnas.1307204111

Kalil, \& Aenurohman, E. A. (2020). Dampak Kreativitas dan Inovasi Produk Terhadap Kinerja UKM di Kota Semarang. Jurnal Penelitian Humaniora, 21(1), 69-7

Kamaluddin, Mahajirin. (2019). Orientasi pasar dan inovasi produk pengaruhnya terhadap keunggulan bersaing (Studi pada UMKM Tenun Gedogan Kita Bima, Jurnal Magister Manajemen Unram, 8(4)

Liu, Y., Lee, J. M., \& Lee, C. (2020). The challenges and opportunities of a global health crisis: The management and business implications of COVID-19 from an Asian perspective. Asian Business $\mathcal{E}$ Management, 19(3), 277-297. https://doi.org/10.1057/s41291-020-00119-x

Lucky, Maskarto \&Rosmad.Nar,a (2021). Inovasi dan Kreativitas Pelaku Usaha UMKM di Era Covid-19, Jurnal IKRA-ITH Ekonomika, 4 (2).

Maritz, Alex; Perenyi, Aron; de Waal, Gerrit; Buck, Christoph. 2020. "Entrepreneurship as the Unsung Hero during the Current COVID-19 Economic Crisis: Australian Perspectives" Sustainability 12, no. 11: 4612. https:// doi.org/10.3390/su12114612

Martens, C. D. P., Machado, F. J., Martens, M. L., Silva, F. Q. P. de O. e, \& Freitas, H. M. R. de. (2018). Linking entrepreneurial orientation to project success. International Journal of Project Management, 36(2), 255-266. https:/ / doi.org/10.1016/j.ijproman.2017.10.005

McClelland, E., Swail, J., Bell, J., \& Ibbotson, P. (2005). Following the pathway of female entrepreneurs: A six-country investigation. International Journal of Entrepreneurial Behavior E Research, 11(2), 84-107. https:/ / doi.org/10.1108/13552550510590527

McCubbin, L. (2001). Challenges to the Definition of Resilience. https://eric.ed.gov/?id=ED458498

Portuguez Castro, M., \& Gómez Zermeño, M. G. (2020). Being an entrepreneur postCOVID-19 - resilience in times of crisis: A systematic literature review. Journal of Entrepreneurship in Emerging Economies, ahead-of-print(ahead-of-print). https:// doi.org/10.1108/JEEE-07-2020-0246 
Prayag, G. (2020). Time for Reset? Covid-19 and Tourism Resilience. Tourism Review International, $24(2-3)$,

179-184. https:/ / doi.org/10.3727/154427220X15926147793595

Rootman Chantal \& Kruger Janine. (2010). Adapting SMME business functions during economic turmoil. Acta Commercii, 10(1), 107-119. https://doi.org/10.10520/EJC11393

Salisu, I., Hashim, N., Mashi, M. S., \& Aliyu, H. G. (2020). Perseverance of effort and consistency of interest for entrepreneurial career success: Does resilience matter? Journal of Entrepreneurship in Emerging Economies, 12(2), 279-304. https:/ / doi.org/10.1108/JEEE-02-2019-0025

Salman Abdou, D.M. (2021), "Future of Egyptian female entrepreneurs post COVID19", World Journal of Entrepreneurship, Management and Sustainable Development, Vol. ahead-of-print No. ahead-of-print. https://doi.org/10.1108/WJEMSD-07-2020$\underline{0094}$

Sawalha, I. H. (2020). A contemporary perspective on the disaster management cycle. Foresight, 22(4), 469-482. https://doi.org/10.1108/FS-11-2019-0097

Sigala, M. (2020a). Tourism and COVID-19: Impacts and implications for advancing and resetting industry and research. Journal of Business Research, 117, 312-321. https://doi.org/10.1016/j.jbusres.2020.06.015

Sigala, M. (2020b). Tourism and COVID-19: Impacts and implications for advancing and resetting industry and research. Journal of Business Research, 117, 312-321. https://doi.org/10.1016/j.jbusres.2020.06.015

Trianasari, N. \&Dharma, A. 2020. Understanding the resiliency and adaptive behaviors of tourism workers during Covid-19. Proceeding on the ICTE

Uğur, N. G., \& Akbiyık, A. (2020). Impacts of COVID-19 on global tourism industry: A cross-regional comparison. Tourism Management Perspectives, 36, 100744. https://doi.org/10.1016/j.tmp.2020.100744

Zafar, A., \& Mustafa, S. (2017). SMEs and Its Role in Economic and Socio-Economic Development of Pakistan (SSRN Scholarly Paper ID 3085425). Social Science Research Network. https:/ / papers.ssrn.com/abstract $=3085425$

Zenker, S., \& Kock, F. (2020). The coronavirus pandemic - A critical discussion of a tourism research agenda. Tourism Management, 81, 104164. https://doi.org/10.1016/j.tourman.2020.104164 